\title{
Energy sustainability alternatives for the Home for the elderly Maty, in the community of Villa Juárez, Aguascalientes
}

\section{Alternativas de sustentabilidad energética para el asilo Hogar del Abuelo Maty, en la comunidad de Villa Juárez, Aguascalientes}

\author{
CASTILLO-ZÁRATE, Ma. Alicia †* \\ Universidad Tecnológica de Aguascalientes, México
}

ID $1^{\text {st }}$ Author: Ma. Alicia, Castillo-Zarate / ORC ID: 0000-0003-0812-1125

DOI: $10.35429 / J U S D .2021 .21 .7 .7 .16$

Received: July 10, 2021; Accepted October 30, 2021

\begin{abstract}
Base on the objectives of the 2030 Schedule, for sustainable development for the benefit of people and the planet and, with the visionary commitment of the Universidad Tecnológica de Aguascalientes to contribute to the sustainable development of the various sectors, this article presents five alternatives of energy sustainability for the benefit of the Hogar del Abuelo Maty nursing home, located in the community of Villa Juárez, municipality of Asientos in the state of Aguascalientes. The document describes the context of this Institution, its energy consumption situation, the dynamics and operating status of equipment that requires electricity for basic healthcare services. Under a sustainability approach, the objective of this work is to provide resilient energy alternatives, aimed at generating, saving or efficient use of energy and caring for the environment. Following the applied research methodology, knowledge of photovoltaic systems allows the development of alternatives to meet a need for social impact. The main contributions derived from any of these are the positive impact generated in reducing the cost of energy consumption, caring for the environment and adult care services provided with clean energy.
\end{abstract}

Sustainability, Energy, Nursing Homes

\begin{abstract}
Resumen
Con base a los objetivos de la Agenda 2030, para el desarrollo sostenible en beneficio de las personas y el planeta $\mathrm{y}$, con el compromiso visionario de la Universidad Tecnológica de Aguascalientes para contribuir al desarrollo sostenible de los diversos sectores, se presenta en este artículo cinco alternativas de sustentabilidad energética en beneficio del asilo Hogar del Abuelo Maty, ubicado en la comunidad de Villa Juárez, municipio de Asientos del estado de Aguascalientes. El documento describe el contexto de esta Institución, su situación del consumo energético, la dinámica y estatus de operación de equipos que requieren electricidad para los servicios básicos asistenciales. Bajo un enfoque de sustentabilidad, el objetivo de este trabajo es proveer alternativas de energía resiliente, orientadas a la generación, ahorro o uso eficiente de energía y, el cuidado al medio ambiente. Siguiendo la metodología de investigación aplicada, el conocimiento de sistemas fotovoltaicos permite desarrollar alternativas para atender una necesidad de impacto social. Las contribuciones principales derivadas de cualesquiera de éstas, son el impacto positivo generado en la disminución del costo del consumo de energía, el cuidado del medio ambiente y los servicios de atención de adultos otorgados con energía limpia.
\end{abstract}

Sustentabilidad, Energía, Asilos

Citation: CASTILLO-ZÁRATE, Ma. Alicia. Energy sustainability alternatives for the Home for the elderly Maty, in the community of Villa Juárez, Aguascalientes. Journal of Urban and Sustainable Development. 2021. 7-21: 7-16

*Correspondence to the author (e-mail: acastillo@utags.edu.mx)

$\uparrow$ Researcher contributing as first author 


\section{Introduction}

Statistical data on population and demographic growth in Aguascalientes project in 2021, 9.8\% corresponding to the older adult population ONAPO, 2018), by 2030 it is expected to represent $9.1 \%$ of the total; however, according to the projection of mortality decrease, by 2050 an increase of this population to $15.8 \%$ is expected, therefore, public and private institutions should consider this growth and provide for the attention to the demands and needs for this sector. In general terms, an increase in the percentage of the 65 and over age group with respect to the total population is projected, since while in 1970 it was $3.9 \%$, in 2015 it represented $5.5 \%$ and, the projection indicates $15.8 \%$ of the total population by 2050 . Under this scenario, the quality and quantity of assistance and health services provided to the elderly are decisive for the improvement of conditions that contribute to the extension of the projected life expectancy.

In this regard, it should be noted that the current operation and activities carried out by State organizations dedicated to the attention and care of the elderly depend to a large extent on the income received from the fees paid by family members and various donations. In order to provide basic care services, those that operate with their own resources or exclusively with donations, have the priority of covering food, water, electricity and thermal services, and frequently their economic solvency (which is why some of them are at risk of closing) limits the provision of complementary care services such as physical therapies, This has an impact on the quality of life of the adult, which is why it is of utmost importance to ensure and expand the availability of resources to provide primary care services and offer complementary services.

To address this situation, specifically in the largest nursing home in the state of Aguascalientes, where monthly energy consumption costs exceed an average of $\$ 10,000$ and, with the primary objective of this institution focused on reducing electricity costs, this document presents five energy sustainability alternatives for the benefit of elderly residents of the Hogar del Abuelo nursing home, oriented to the generation, saving or efficient use of energy and care for the environment.
The different alternatives are developed in a first stage of intervention to this problem, and each one shows its respective amount and return on investment, leaving open a second stage for the search of resources that allow the implementation of any of these.

In this way, the document includes the following sections: Background of Hogar del Abuelo, the detected problem, the proposal of attention to the problem, the objective of this intervention, the detailed description of the work methodology used and, as results, the different proposals of solution as alternatives of energetic sustainability, likewise in the conclusions section it is emphasized on the fulfillment of the sustainability approach and the impact that all the proposals generate in the economic, environmental and social fields.

The added value that any of the alternatives will provide with their implementation will be the decrease in the cost of energy consumption, as well as the generation of energy from alternative sources to continue offering basic and complementary services in a socially and environmentally sustainable space.

\section{Background}

The "Casa de Descanso para Ancianos" also known as "Hogar del Abuelo Maty", was founded in 1979 and inaugurated on February 14, 1981; it was founded by Mrs. Carolina Villanueva de García and her son Mr. Carlos García Villanueva, with the purpose of offering the elderly the opportunity to live a dignified and healthy old age. Currently, Mr. Carlos García presides this institution.

The Daughters of Charity of St. Vincent de Paul have collaborated with this organization and at the same time, a board of trustees is formed with representative people in the State of Aguascalientes; it also has the support of public and private institutions that have collaborated to provide assistance to the elderly.

The Hogar del Abuelo is characterized for being the institution in the state that has benefited more people since its inauguration, since it has assisted more than a thousand elderly adults in vulnerable and marginalized situations in Aguascalientes. 
This organization is located in the town of Villa Juarez, which belongs to the municipality of Asientos and currently serves 60 to 80 elderly people per year, to whom it offers a permanent home, with food services, medical and spiritual care, physical therapies, laundry, hairdressing, personal grooming, as well as personalized care necessary for their physical and emotional well-being; the support also includes funeral services.

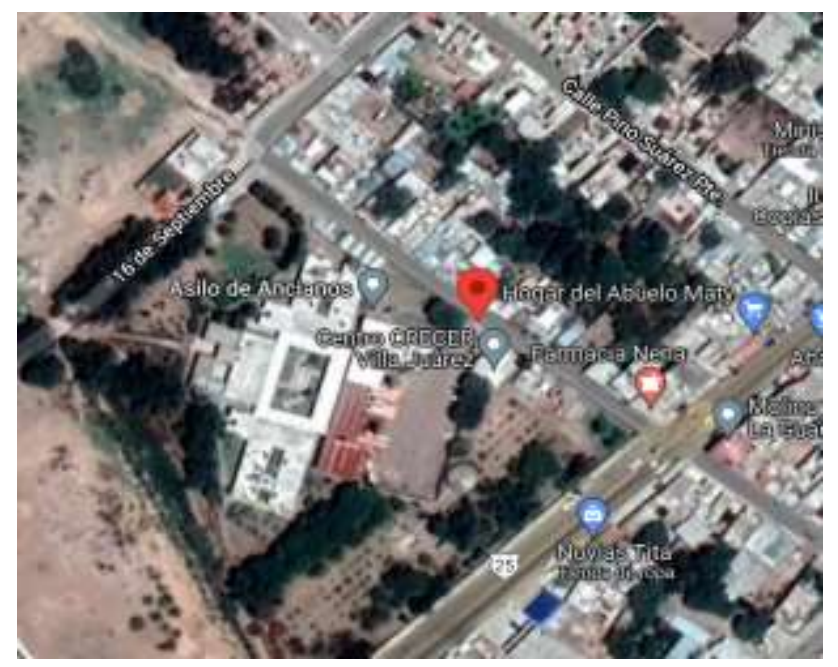

Figure 1 Geographical location of Hogar del Abuelo Source: www.googlemaps.com.mx

In addition to caring for the elderly, the "Maty" rest home serves as the Basic Rehabilitation Unit of the Integral Family Development System (DIF) for the municipality of Asientos, offering physical and rehabilitation therapies free of charge. It has also worked with collegiate bodies such as the State Committee for Health and Attention to Aging, the Technical Council for Private Charity and the National Network of CSOs in Health.

\section{Problem}

For many years, the Hogar del Abuelo Maty received support from the company "Bordados Maty", however, with the decline of the textile industry in the state, the institution has sought other ways to obtain resources, currently subsisting through public and private donations. On the other hand, even though the pandemic situation has temporarily restricted the services of physical therapies and rehabilitation of older adults, as well as collective care events, for the residents of this Institution, there are food services, medical attention, laundry, hairdressing, personal grooming and personalized care, which evidently cannot be suspended.
Being these essential services those that require the constant consumption of thermal and electric energy, however in the last years, the average monthly cost of this service has averaged $\$ 12,000$. 00, reaching in some months up to $\$ 18,000.00$, hence the supply and consumption of energy represents an area of opportunity to diversify its generation sources, optimize its use and reduce its cost.

\section{Description of the proposal for the development of sustainable alternatives}

To ensure the minimum availability of energy required for care services, it is important to analyze the dynamics of energy consumption and, if necessary, adapt the Hogar del Abuelo's facilities under an energy sustainability approach, which will allow, on the one hand, to reduce the cost of thermal and electrical energy consumption and, on the other hand, to provide alternative sources of energy generation for the Hogar del Abuelo's facilities and, if necessary, to reduce the cost of thermal and electrical energy consumption, provide alternative sources of energy to continue offering basic services in a socially and environmentally sustainable space, in which priority is given to the comprehensive care of adults, strengthening social coexistence through the diversification of interactive activities, promoting the care of environmental resources with the appropriate use of solar technology, and at the same time reducing the cost of energy consumption for such actions.

Considering the situation and dynamics of energy consumption in the Hogar del Abuelo, as well as the alignment towards the objectives of the 2030 Agenda for sustainable development for the benefit of people and the planet, this project develops proposals for energy sustainability with the use of solar technology, as alternatives to meet the energy demand and reduce the cost of energy consumption.

\section{Objective}

To provide resilient energy alternatives, through the proposals of solar energy systems developed as sustainable alternatives, that provide electric energy for the basic care services required by the older adults of the Hogar del Abuelo Maty. 


\section{Methodology}

Under the Applied Research approach, the knowledge of photovoltaic systems allows the development of alternatives to meet and improve a need of social impact, specifically the reduction of the cost of electricity consumption in the Hogar del Abuelo, therefore, this intervention is developed in the following stages:

\section{Search for support and backing from governmental institutions.}

The support of the State Integral Family Development (DIF) was sought for the development of the proposal. The response was positive, committed, and collaborative, mainly with the information required for the development of the proposals and access to the facilities of the Hogar del Abuelo.

\section{Identification of the dynamics of energy consumption in the Hogar del Abuelo Maty's facilities.}

a) The facilities have a well with a dynamic load depth of $120 \mathrm{~m}$, in which a submersible pump with unknown power but calculated at $6 \mathrm{HP}$, extracts the water that supplies a tank with a capacity of $84 \mathrm{~m} 3$.

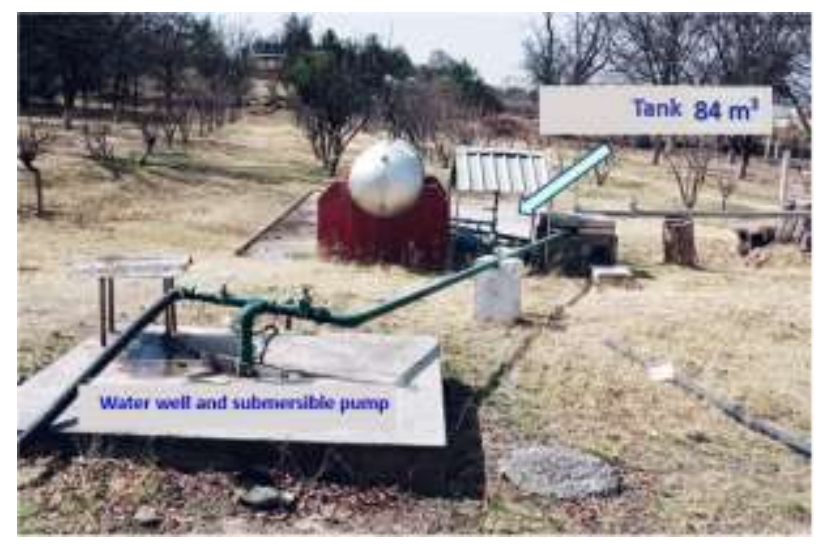

Figure 2 Well, submersible pump and reservoir Source: Own Elaboration

b) The pumping equipment (supply pump) for the restrooms sends water to sinks, toilets and three 600-liter tanks used only for showers. This pump is activated every 5 minutes throughout the day and, although its nominal power is $3 \mathrm{HP}$, during operation it operates at $6.4 \mathrm{HP}$, this being the equipment with the highest energy consumption.

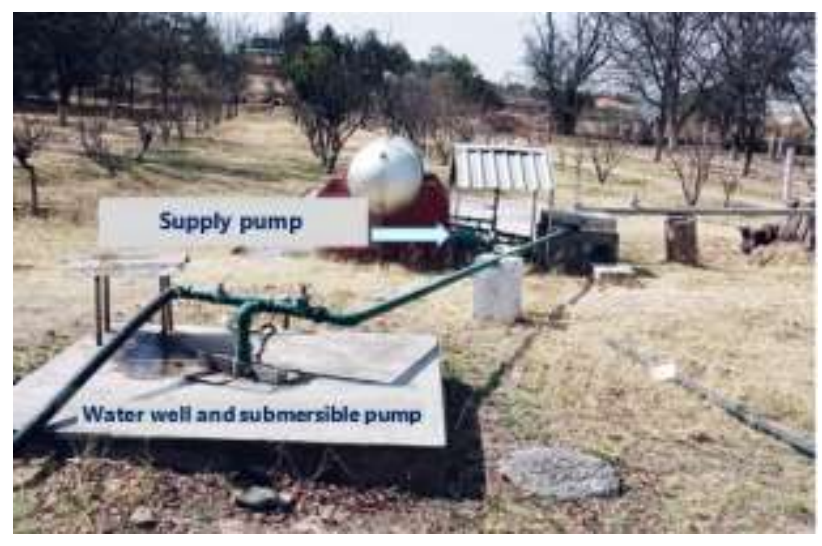

Figure 3 Well, submersible pump and supply pump Source: Own Elaboration

c) The kitchen has a cold room and a freezer.
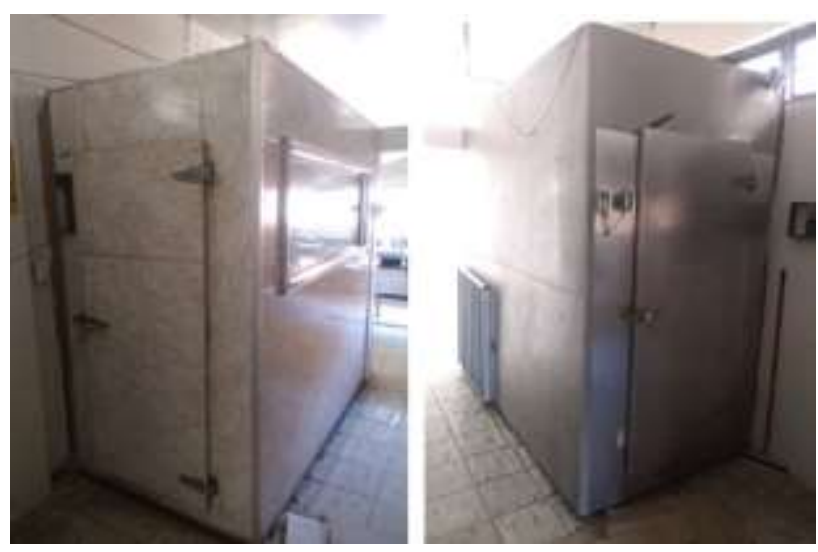

Figure 4 Cold storage and freezer Source: Own Elaboration

d) In the laundry room has five washing machines and two dryers.

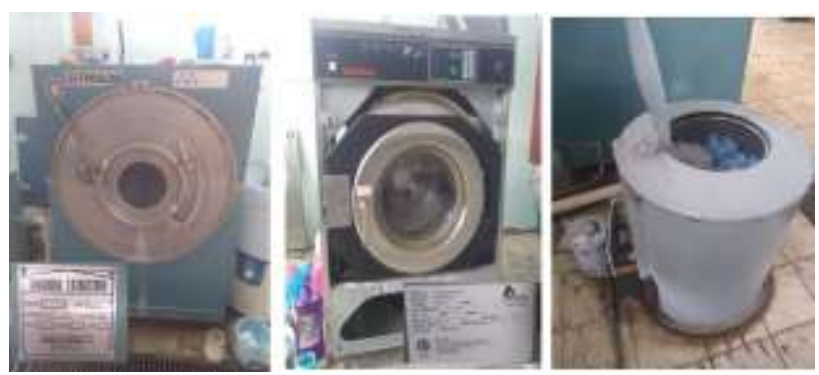

Figure 5 Washers and dryers

Source: Own Elaboration

e) The dormitories and corridors are equipped with energy-saving lighting.

f) In the asylum's load center, the power supply to the facilities is supplied to the following sections:

- Men's dormitory and kitchen

- Laundry and boiler

- Women's dormitory and south corridor

- Well pump

CASTILlO-ZÁRATE, Ma. Alicia. Energy sustainability alternatives for the Home for the elderly Maty, in the community of Villa Juárez, Aguascalientes. Journal of Urban and Sustainable Development. 2021 
December 2021 Vol.7 No.21 7-16

\section{- $\quad$ Water supply pump for services \\ - $\quad$ Clinic, chapel and auditorium}
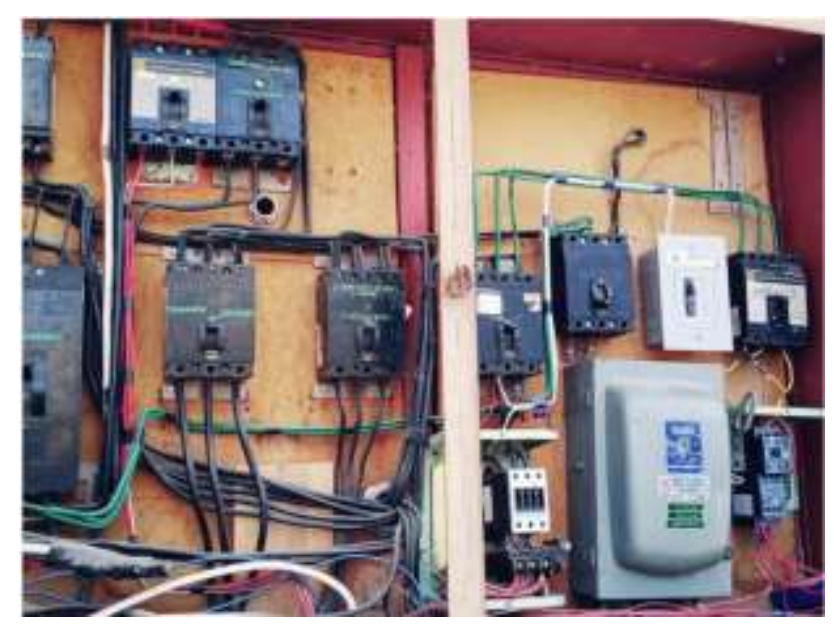

Figure 6 Load Center

Source: Own Elaboration

g) The history of electricity consumption during 2020, shows in Graph 1, a variability of consumption in a range of 2201 to $6077 \mathrm{KWh}$ per month, which places this Institution with a tariff as a consumer of High Demand Medium Voltage (GDMT), generating a consumption cost in a range ranging from $\$ 8,832.00$ to $\$ 18,927.00$.

Historical of energy consumption and cost 2020

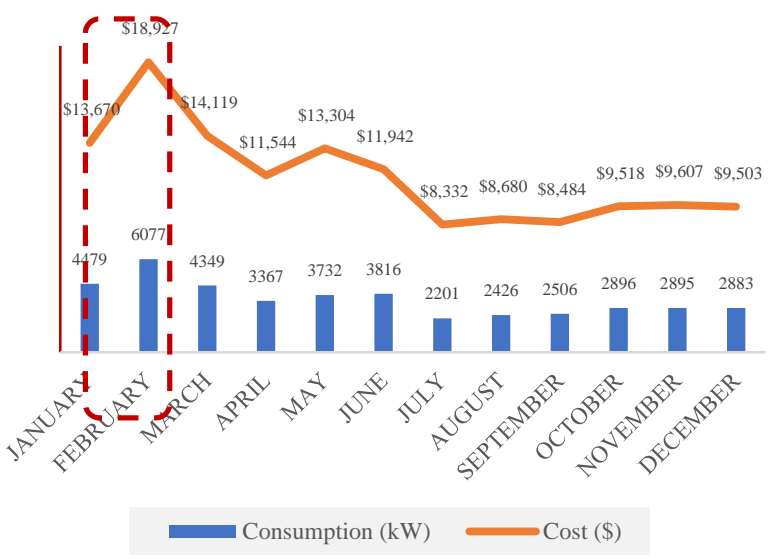

Graph 1 Historical energy consumption and cost -2020 Source: Own elaboration with information from www.cfe.mx

h) Status of energy consumption in the "Hogar del Abuelo Maty" nursing home.

\begin{tabular}{|c|c|c|}
\hline Month & Consumption (kW) & Cost (\$) \\
\hline January 20 & 4479 & $\$$ \\
\hline February 20 & 607 & $18,92 \pi$ \\
\hline March 20 & 4349 & 14,119 \\
\hline April 20 & 3367 & 11,544 \\
\hline May 20 & 3732 & 13,304 \\
\hline June 20 & 3816 & 11,942 \\
\hline July 20 & $\overline{2} 2 \overline{0} \overline{1}=$ & $\overline{8,3 \overline{3}} 1$ \\
\hline August 20 & $2 \overline{4} 26$ & $\overline{8}, \overline{6} \overline{80}$ \\
\hline September 20 & 2506 & 8,484 \\
\hline October & 2896 & 9,518 \\
\hline November & 2895 & 9,607 \\
\hline December & 2883 & 9,503 \\
\hline Total annual & $41627 \mathrm{~kW}$ & 137,630 \\
\hline Monthly average & $3468.91 \mathrm{~kW}$ & 11,469 \\
\hline
\end{tabular}

Table 1 Historical Energy Consumption and Cost 2020 Source: www.cfe.mx

\begin{tabular}{|l|l|}
\hline \multicolumn{1}{|c|}{ Energy tariff: } & \multicolumn{1}{c|}{$\begin{array}{c}\text { GDMTO (Great Demand } \\
\text { Medium Voltage Ordinary) }\end{array}$} \\
\hline Division: & Bajio \\
\hline Service number: & 106820100011 \\
\hline Meter number: & 307 CGD \\
\hline KWh/month: & $3,468.91$ \\
\hline Amount/month: & $\$ 11,469$ \\
\hline
\end{tabular}

Table 2 Average monthly energy consumption and cost Source: Own Elaboration

This tariff will be applied to services that use energy for any purpose, supplied at medium voltage, with a demand of less than $100 \mathrm{~kW}$.

\section{i) CFE fees applicable per month}

Fees apply per month according to the geographic region (CFE, 2021). For Aguascalientes (Bajío region), the rate is:

\begin{tabular}{|c|c|c|c|c|}
\hline Tariff & Description & Cargo & Units & FEB-21 \\
\hline \multirow[t]{4}{*}{ GDMTO } & \multirow{4}{*}{$\begin{array}{l}\text { High demand } \\
\text { in ordinary } \\
\text { medium } \\
\text { voltage }\end{array}$} & Fixed & $\begin{array}{l}\$ \\
\text { mes }\end{array}$ & 478.51 \\
\hline & & $\begin{array}{l}\text { Variable } \\
\text { (Energy) }\end{array}$ & $\begin{array}{ll} & / \\
\mathrm{kWh}\end{array}$ & 1.295 \\
\hline & & Distribution & $\$ / \mathrm{kW}$ & 100.61 \\
\hline & & Capacity & $\$ / \mathrm{kW}$ & 278.15 \\
\hline
\end{tabular}

Table 3 Energy supply tariff charges in the GDMTO tariff

Source: www.cfe.mx

The final tariff charges for basic supply described in this section correspond to the integration of charges for Transmission, Distribution, CENACE Operation, Basic Supplier Operation, Non-MEM Ancillary Services, Energy and Capacity. 


\section{Development of alternatives for electricity supply}

Taking into account the dynamics of energy consumption, specifically the operation of the supply pump described in paragraph c) and, considering that the amounts of investment in photovoltaic modules can have a great impact for this Institution, five alternatives are developed, with different scope in reducing the cost of energy consumption and use, all of them under the approach of sustainability.

\section{Results}

\section{Alternative 1}

Generation of energy from Interconnected Photovoltaic Systems (SFV-I), with different dimensions to partially cover the energy consumption of Hogar del Abuelo.

Different dimensions of SFV-I are presented to cover part of the energy demand indicated in the CFE bill.

\begin{tabular}{|l|r|r|r|r|}
\hline $\begin{array}{c}\text { Number } \\
\text { of } \\
\text { modules } \\
\text { in SFV } \\
435 \mathrm{~W}\end{array}$ & $\begin{array}{c}\text { Estimated } \\
\text { payment } \\
\text { consumption }\end{array}$ & Savings & $\begin{array}{c}\text { Return on } \\
\text { investment } \\
\text { years(a) } \\
\text { months (m) }\end{array}$ & $\begin{array}{c}\text { Investment } \\
\text { cost }\end{array}$ \\
\hline 58 & $\$ 1,785.92$ & $\$ 10,252.98$ & 5 a $2 \mathrm{~m}$ & $\$ 796,752.92$ \\
\hline 42 & $\$ 3,495.26$ & $\$ 8,543.65$ & 4 a $2 \mathrm{~m}$ & $\$ 619,446.96$ \\
\hline 34 & $\$ 4,770.78$ & $\$ 7,268.15$ & 3 a $7 \mathrm{~m}$ & $\$ 540,684.12$ \\
\hline 22 & $\$ 7,342.51$ & $\$ 4,696.39$ & 2 a $8 \mathrm{~m}$ & $\$ 405,851.52$ \\
\hline 10 & $\$ 9,914.22$ & $\$ 2,124.68$ & 2 a $2 \mathrm{~m}$ & $\$ 330,349.44$ \\
\hline
\end{tabular}

Table 1 Amount and return on investment of Alternative 1: Different size of SFV-I to cover the partial consumption indicated in the CFE bill

Source: Own elaboration with YRN-Solar company

\section{Characteristics of Alternative 1:}

- $\quad$ The energy generated by the SFV-I covers only part of the asylum's energy demand; the rest is consumed from the CFE grid.

- $\quad$ There is no significant return of power generated to the CFE grid. Most of the energy generated by the SFV-I is consumed by the supply pump.

- $\quad$ The water supply pump from the cistern to the utilities is kept on every 5 minutes throughout the day (at least 12 hours) all year round. This is the equipment with the highest energy consumption.

- The hydraulic installations of the nursing home remain unchanged.
- Due to the high consumption, the electricity tariff assigned by CFE is GDMTO (high demand medium voltage ordinary), so there is a high demand cost WITHOUT energy consumption subsidy.

- The investment costs include the services of the Verification and Inspection Unit, as well as the bidirectional meter, since the tariff is for the Ordinary Medium Voltage High Demand (GDMTO).

\section{Alternative 2}

Autonomous Photovoltaic System (SFV-A) to cover only the demand of the hydraulic system.

\begin{tabular}{|c|c|c|c|c|}
\hline Concept & Unit & Quantity & $\begin{array}{c}\text { Technical } \\
\text { characteristics }\end{array}$ & $\begin{array}{l}\text { Amount of } \\
\text { investment }\end{array}$ \\
\hline $\begin{array}{l}\text { Monocrystalline } \\
\text { PV modules }\end{array}$ & parts & 33 & $\begin{array}{l}410 \quad \mathrm{~W} \\
\text { CONNERA }\end{array}$ & $\$ 113,224.14$ \\
\hline $\begin{array}{l}\text { Submersible } \\
\text { pumps for wells } \\
\text { and reservoirs }\end{array}$ & parts & 2 & $\begin{array}{l}5 \text { y } 10 \mathrm{HP}, 3 \mathrm{~F}, \\
2 ", 230 \mathrm{VCA}\end{array}$ & $\$ 57,167.24$ \\
\hline $\begin{array}{l}\text { Pump handling } \\
\text { service }\end{array}$ & service & 1 & --- & $\$ 13,151.72$ \\
\hline $\begin{array}{l}\text { Solar pumping } \\
\text { system accessories }\end{array}$ & kit & 2 & $\begin{array}{l}\text { Accessories for } 2 \\
\text { pumps }\end{array}$ & $\$ 76,488.62$ \\
\hline $\begin{array}{l}\text { Anodized structure } \\
\text { for installation }\end{array}$ & kit & 1 & $\begin{array}{l}\text { Anodized } \\
\text { aluminum }\end{array}$ & $\$ 28,163.79$ \\
\hline $\begin{array}{l}\text { Photovoltaic } \\
\text { installation } \\
\text { material }\end{array}$ & Kit & 1 & $\begin{array}{l}\text { PV installation } \\
\text { accessories }\end{array}$ & $\$ 34,991.38$ \\
\hline $\begin{array}{l}\text { SFV labor, } \\
\text { installation and } \\
\text { commissioning } \\
\text { service }\end{array}$ & \begin{tabular}{|l} 
service \\
\end{tabular} & 1 & $\begin{array}{l}\text { Installation of } \\
\text { the SFV }\end{array}$ & $\$ 32,658.62$ \\
\hline tanks & parts & 6 & $\begin{array}{l}5 \text { de } 5000 \mathrm{lt} \\
1 \mathrm{de} 10000 \mathrm{lt}\end{array}$ & $\$ 108,350.00$ \\
\hline $\begin{array}{l}\text { Support structure } \\
\text { for tanks }\end{array}$ & Lot & 1 & $\begin{array}{l}\text { Bases and } \\
\text { reinforcement } \\
\text { for tank supports }\end{array}$ & $\$ 40,655.17$ \\
\hline $\begin{array}{l}\text { Hydraulic } \\
\text { installation } \\
\text { material }\end{array}$ & Lot & 1 & $\begin{array}{l}\text { Piping, valves, } \\
\text { elbows }\end{array}$ & $\$ 41,762.00$ \\
\hline $\begin{array}{l}\text { Hydraulic } \\
\text { installation service }\end{array}$ & Lot & 1 & $\begin{array}{l}\text { Installation } \\
\text { service }\end{array}$ & $\$ 8,448.28$ \\
\hline & & \multicolumn{2}{|l|}{\begin{tabular}{|l|} 
Subtotal \\
\end{tabular}} & $\$ 555,050.97$ \\
\hline & & \multicolumn{2}{|l|}{ IVA } & $\$ 88,808.15$ \\
\hline & & \multicolumn{2}{|l|}{ Total } & $\$ 643,859.12$ \\
\hline & & \multicolumn{2}{|c|}{\begin{tabular}{|l|} 
Return on investment \\
\end{tabular}} & $\begin{array}{l}4 \text { years } \\
\text { months }\end{array}$ \\
\hline
\end{tabular}

Table 2 Amount and return on investment of Alternative 2: SFV-A to cover the demand of the hydraulic system (pumps)

Source: Own elaboration with information from YRNSolar company

\section{Characteristics of Alternative 2:}

- $\quad$ The SFV-A generates energy that is consumed by the pumping system.

- Although the asylum rate is GDMTO, the installation of this SFV-A does NOT require consideration of the services of the Verification Unit, the inspection unit and the bidirectional meter. 
- With this SFV-A, five hours of solar energy is efficiently used for the operation of both pumps, during which time the amount of water required for the services is supplied and the constant consumption of energy from the CFE network is eliminated, especially for the supply pump.

- $\quad$ It is recommended that the well pumps (submersible) be replaced with new technology equipment that supplies the amount of water required for the showers and other services directly from the well.

- The adaptation and expansion of the asylum's hydraulic system is considered in order to efficiently take advantage of the 5 hours of sunlight by placing water tanks on the roof of the dormitories and the community area (religious people).

A 10,000 liter central water tank will be filled by the solar pumping system, and from there the remaining 5 tanks with a capacity of 5,000 liters will be filled by gravity, as well as the existing tanks for the showers.

- It is also recommended to replace the supply pump (surface pump) for alternative water supply required from the storage tank to the toilets (sinks, toilets and showers), with another submersible pump that will have the option of connection to the autonomous solar pumping system and connection to the CFE network only to be used in case of cloudy days.

- With the elimination of energy consumption by the pumping system, the possibility of changing the electricity tariff can be considered, which would have a greater impact on the monthly energy cost.

\section{Alternative 3:}

Interconnected Photovoltaic System to supply energy to pumps.

\begin{tabular}{|c|c|c|c|c|}
\hline Concept & Unit & Quantity & $\begin{array}{c}\text { Technical } \\
\text { characteristics }\end{array}$ & $\begin{array}{l}\text { Amount of } \\
\text { investment }\end{array}$ \\
\hline $\begin{array}{l}\text { Polycrystalline } \\
\text { modules }\end{array}$ & parts & 26 & $450 \mathrm{~W}$ TRINA & $\$ 121,394.00$ \\
\hline Central Inverter & parts & 1 & $6 \mathrm{~kW}$ & $\$ 34,200.00$ \\
\hline $\begin{array}{l}\text { Photovoltaic and } \\
\text { electrical } \\
\text { equipment and } \\
\text { interconnection } \\
\text { protections }\end{array}$ & $\mathrm{kW}$ & 11.7 & $\begin{array}{l}\text { Connection } \\
\text { material }\end{array}$ & $\$ 35,100.00$ \\
\hline $\begin{array}{ll}\text { Engineering, } \\
\text { design } \\
\text { installation }\end{array}$ & $\mathrm{kW}$ & 11.7 & $\begin{array}{l}\text { Tailor-made } \\
\text { service }\end{array}$ & $\$ 32,760.00$ \\
\hline $\begin{array}{l}\text { Anodized structure } \\
\text { for installation / } \\
\text { adjustable pole } \\
\text { base }\end{array}$ & pieza & 1 & $\begin{array}{l}\text { Anodized } \\
\text { aluminum }\end{array}$ & $\$ 22,189.00$ \\
\hline $\begin{array}{lr}\text { Unit } & \text { for } \\
\text { Verification } & \text { of } \\
\text { Electrical } & \\
\text { Installations } & \\
\text { (UVIE) } & \\
\end{array}$ & service & 1 & $\begin{array}{l}\text { Verification unit to } \\
\text { guarantee } \\
\text { compliance with } \\
\text { NOM-001- SEDE- } \\
2012 \text { (DOF, 2019) }\end{array}$ & $\$ 55,000.00$ \\
\hline $\begin{array}{l}\text { Electrical } \\
\text { Interconnection } \\
\text { Inspection Unit } \\
\text { (UIIE) }\end{array}$ & service & 1 & $\begin{array}{l}\text { Verification unit } \\
\text { for interconnection } \\
\text { certification, } \\
\text { endorsed by the } \\
\text { Energy Regulatory } \\
\text { Commission } \\
\text { (CRE). }\end{array}$ & \\
\hline Bidirectional meter & piece & 1 & $\begin{array}{l}\text { Meter for reading } \\
\text { the supply and } \\
\text { injection of energy } \\
\text { to the CFE } \\
\text { network. }\end{array}$ & $\$ 40,000.00$ \\
\hline & \multicolumn{3}{|c|}{ Subtotal } & $\$ 340,643.00$ \\
\hline & \multicolumn{3}{|l|}{ Iva } & $\$ 54,502.88$ \\
\hline & \multicolumn{3}{|l|}{ Total } & $\$ 395,145.88$ \\
\hline & \multicolumn{3}{|c|}{ Return on investment } & $\begin{array}{l}2 \text { years } 9 \\
\text { months }\end{array}$ \\
\hline
\end{tabular}

Tabla 3 Amount and return on investment of Alternative 3: SFV-I to cover energy demand in pumps only

Source: Own elaboration with information from YRNSolar.

\section{Characteristics of Alternative 3:}

- $\quad$ Well and supply pumps consume 50\% of the total energy required by the nursing home.

- $\quad$ The SFV-I generates power to supply well and supply pumps throughout the day.

- $\quad$ The SFV-I generates $1,723 \mathrm{~kW}$ of the total $3,488 \mathrm{~kW}$ consumed by the nursing home (50\%).

- $\quad$ There is no significant return of power generated to the CFE grid. Most of the energy generated by the SFV-I is consumed by the supply pump.

- Since the nursing home's tariff is GDMTO, it is necessary to consider the services of the Verification Unit, the inspection unit and the bidirectional meter.

Since the consumption does not change, the tariff remains at GDMTO, which does not make it possible to change the tariff, even if the system is in place. 
The asylum's hydraulic system remains in the same conditions, especially with the energy overload on the supply pump, the equipment with the highest energy consumption.

\section{Alternative 4}

Autonomous Photovoltaic System (SFV-A) for supply pump replaced by submersible pump.

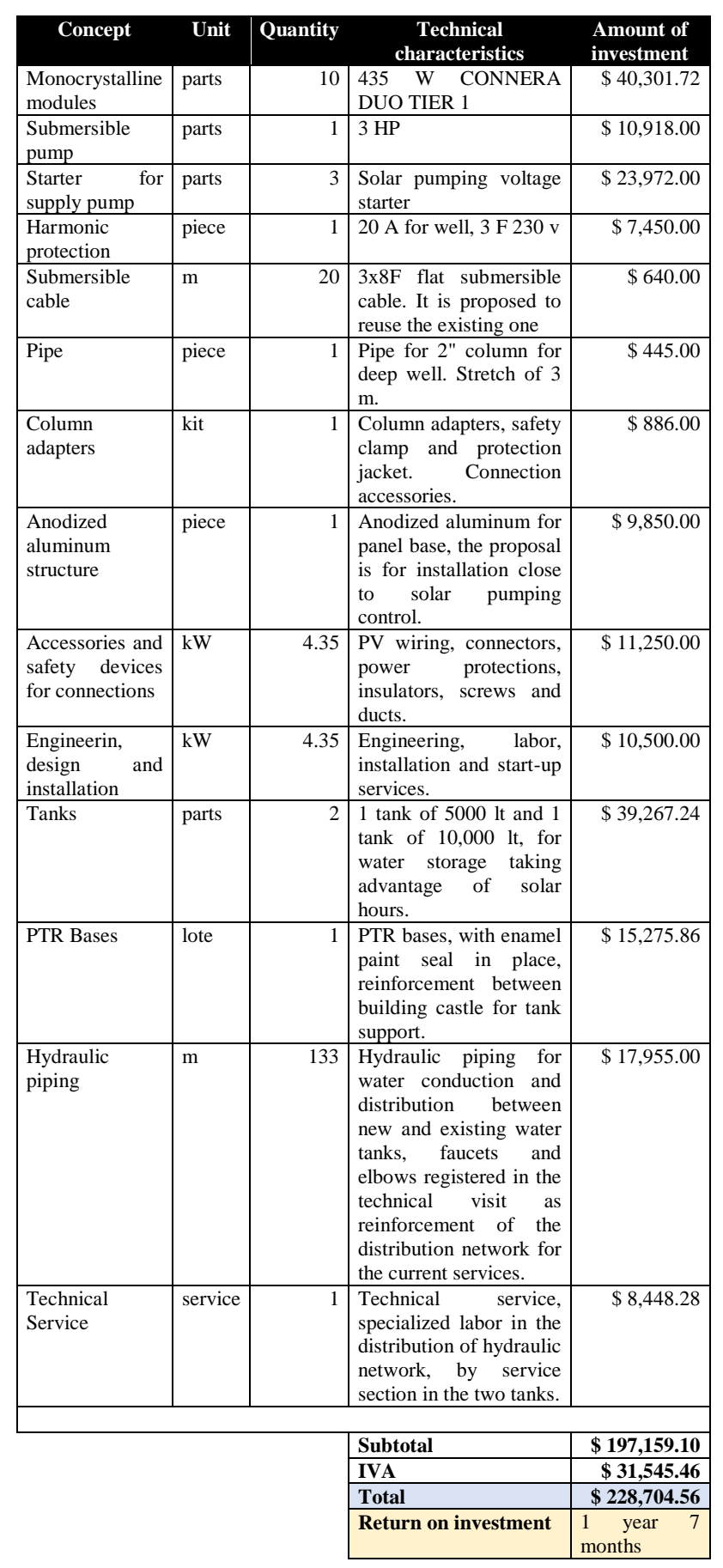

Table 7 Amount and return on investment for Alternative 4: SFV-A to cover demand for supply pump replaced by submersible pump

Source: YRN-Solar Company

\section{Characteristics of Proposal 4:}

This proposal suggests the replacement of the supply pump with a submersible one and of lower operating capacity (3HP) with the intention that it will only be activated three or four times during the day (approximately one hour running for each operating occasion) to cover the demand of the nursing home.

To this end, it is recommended to reinforce the hydraulic system with the installation of a 10,000 liter central tank, which will be supplied by the SFV-A, as well as a 5,000 liter tank to cover the kitchen and laundry area, the latter being supplied by gravity with the central tank. The three existing tanks of 600 liters each will also be supplied by gravity.

Considering that the daily consumption of the nursing home is 38,000 liters, the supply pump must supply 16,600 liters each time it is activated ( 3 or 4 times). These 16,600 liters will be distributed in the central tank $(10,000$ liters $)$, the laundry and kitchen tank (5,000 liters) and the 3 shower tanks (1,800 liters).

- With this operation scheme, the supply pump will be operating an average of 4 hours per day.

Likewise, the well pump will only work approximately 3 hours per day to supply the cistern with the 38,000 liters required by the nursing home.

- The SFV-A generates power to cover only the supply pump load for approximately 4 hours net. This pump will have an alternate connection to the CFE network, in case it is needed at night.

Although the asylum tariff is GDMTO, the installation of this SFV-A does NOT require consideration of the services of the Verification Unit, the inspection unit and the bidirectional meter.

The reduction of the operation time of the pumps and therefore the energy consumption, makes it possible to change the electricity tariff after 2 or 3 months. 


\section{Alternative 5}

Efficient use of energy from the CFE grid with replacement of the supply pump with a new technology at $3 \mathrm{HP}$.

\begin{tabular}{|c|c|c|c|c|}
\hline Concept & Uni & Canti & $\begin{array}{c}\text { Technical } \\
\text { characteristics }\end{array}$ & $\begin{array}{l}\text { Amount of } \\
\text { investment }\end{array}$ \\
\hline Surface pump & piece & 1 & $\begin{array}{l}3 \quad \mathrm{HP}, \quad 2 \quad " \\
\text { pressurized } \\
\text { PRISMA }\end{array}$ & $\$ 10,700.42$ \\
\hline $\operatorname{tank}$ & piece & 1 & 10,000 lt capacity & $\$ 25,000.00$ \\
\hline $\begin{array}{l}\begin{array}{l}\text { Support } \\
\text { structure for } \\
\text { water tank }\end{array} \\
\end{array}$ & piece & 1 & PTR structure & $\$ 10,275.86$ \\
\hline $\begin{array}{l}\text { Water tank } \\
\text { installation }\end{array}$ & service & 1 & $\begin{array}{l}\text { Laying of structure } \\
\text { and installation of } \\
\text { water tank }\end{array}$ & $\$ 12,250.00$ \\
\hline $\begin{array}{l}\text { Hydraulic } \\
\text { installation } \\
\text { material }\end{array}$ & kit & 1 & Elbows, wrenches & $\$ 1,800.00$ \\
\hline $\begin{array}{l}\text { Hydraulic } \\
\text { equipment } \\
\text { installation } \\
\text { service } \\
\end{array}$ & service & 1 & $\begin{array}{lr}\text { Service } & \text { for } \\
\text { installation } & \text { of } \\
\text { hydraulic equipment }\end{array}$ & $\$ 8,448.28$ \\
\hline & & \multicolumn{2}{|c|}{ Subtotal } & $\$ 68,474.56$ \\
\hline & & \multicolumn{2}{|c|}{ IVA } & $\$ 10,955.93$ \\
\hline & & \multicolumn{2}{|c|}{ Total } & $\$ 79,430.49$ \\
\hline & & \multicolumn{2}{|c|}{ Return on investment } & 7 months \\
\hline
\end{tabular}

Table 8 Amount and return on investment for Alternative 5: Replacement of supply pump with a new technology pump with $3 \mathrm{HP}$

Source: Own elaboration with information from YRNSolar

\section{Characteristics of Alternative 5:}

- This proposal suggests replacing the supply pump with one of recent technology and lower operating capacity (3HP) with the intention that it will only be activated three times during the day (approximately one hour running for each operating occasion) to cover the demand of the nursing home.

- $\quad$ For this purpose, it is recommended to reinforce the hydraulic system with the installation of a 10,000 liter central tank to supply by gravity the kitchen and laundry area, as well as the three existing tanks of 600 liters each.

- Considering that the daily consumption of the nursing home is 38,000 liters, the supply pump must meet this requirement when activated three or four times.

- With this operation scheme, the supply pump will be operating an average of 4 hours per day.

- The well pump will only work approximately 3 hours per day to supply the cistern with the 38,000 liters required by the nursing home.
- $\quad$ There is no SFV-I installation, so the energy required to operate the pumps is taken from the CFE grid.

- $\quad$ By reducing the operation time of the pumps, a reduction in the energy consumption of the network is expected, making it possible to change the electricity tariff after 2 or 3 months, according to the drop in consumption.

\section{Acknowledgements}

Special thanks to the company YRN-Solar for their support, advice, design support and investment quotation during the development of the proposals.

\section{Conclusions}

- Under the sustainability approach, all the alternatives are viable because they comply with at least one of the following purposes: generation, saving or efficient use of energy and, consequently, care for the environment.

- The sustainability approach in Alternative 1: SFV-I energy generation with different dimensions, fulfills the purpose of the system oriented to the generation and use of clean energy.

- $\quad$ For the case of Alternative 2: SFV-A to cover the demand of hydraulic pumps, the sustainability approach is fulfilled with the purpose of generation and efficient use of electric energy in the hydraulic system.

- Alternative 3: SFV-I for supplying energy to pumps, aimed at the generation of energy by the SFV-I exclusively for the demand required by the pumps, decreases the consumption of the CFE network, and at the same time decreases the cost of consumption. The purpose of "Alternative 4: SFV-A for supply pump replaced by submersible pump" is oriented to the generation and consumption of energy only for the submersible supply pump; thus, it meets the sustainability criteria by saving energy consumption supplied by the grid. 
- The sustainability approach in "Alternative 5: Replacement of supply pump by a new technology with 3HP", meets the purpose of the system oriented to the efficient use of energy from the CFE grid for supply pump operation.

- $\quad$ These purposes also represent a positive impact mainly in the following aspects:

a. Economic. There is a decrease in the cost of energy consumption.

b. Environmental. The clean generation of energy through photovoltaic modules avoids pollution caused by the emission of greenhouse gases from conventional sources.

c. Social: The basic services to the elderly are not limited, since the supply of energy by clean sources and the saving of its cost, opens the possibility for Hogar del Abuelo to consider offering other complementary services.

- Finally, the proposals indicated here represent an area of opportunity for the search of resources in different governmental institutions, research, development or applied technology, that will allow the implementation of some of the alternatives, for the benefit of this sector of the population and the environment.

\section{References}

CFE. (19 de Febrero de 2021). CFE. Obtenido de

https://app.cfe.mx/Aplicaciones/CCFE/Tarifas/ TarifasCRENegocio/Tarifas/GranDemandaMT O.aspx

CONAPO. (2018). Colección Proyecciones de la población de México y las entidades federativas 2016-2050. Aguascalientes. México.

DOF. (19 de 11 de 2019). Diario Oficial de la Federación. Recuperado el 14 de 04 de 2021, de

https://www.gob.mx/cms/uploads/attachment/fi le/512096/NOM-001-SEDE-2012.pdf

IMPLAN, c. d. (2019). Panorama demográfico de Aguascalientes 2015-2016.
IMPLAN, I. M. (2019). En 2019, Proyecciones de la Población de México y de las Entidades. AGUASCALIENTES.

PDM. (2019). Plan de Desarrollo Municipal 2019-2020. Aguascalientes.

Serrano Rangel, R. A. (2019). Datos Aguascalientes. Coordinación Genreal de Planeación y Proyectos (CLAP), Aguascalientes.

Vargas Cordero, Z. R. (2009). LA INVESTIGACIÓN APLICADA: UNA FORMA DE CONOCER LAS REALIDADES CON EVIDENCIA. (REDALyC, Ed.) Revista Educación, 33(1), 155-165. Recuperado el 16 de 03 de 2021, de https://www.redalyc.org/pdf/440/44015082010. pdf 